\title{
TRADISI SIRIT MASYARAKAT LAMPUNG DALAM PERSPEKTIF HUKUM KELUARGA
}

\author{
Nency Dela Oktora
}

Institut Agama Islam Negeri Metro

Email : nencydelaoktora31@yahoo.com

\begin{abstract}
Marriage is one of the laws that apply to all the creatures of Allah are dead. Sirit is carry off a woman by force, deceit sense, even violence to marry. Problematic is that Sirit is not in accordance with the concept of marriage in Islam is that her marriage was valid if it meets the requirements of marriage is one of the conditions is the willingness between two potential partner, which may mean that that marriage should not be forced to either party. The formulation of the problem are (1) the factors behind the occurrence of Sirit?, (2) How is the operational / implementation and impact Sirit?, and (3) How Sirit Lampung ethnic communities in the Perspective of Islamic Family Law. Objective: (1) Knowing the factors that cause Sirit in Lampung ethnic society, (2) Explain the operational/ implementation Sirit and the impact Sirit, (3) Analyze Sirit Lampung ethnic society in the perspective of the Islamic Family Law. Data collection methods used was interviews and documentation. Data analysis method used is qualitative method. Based on the analysisof, it was concluded that the factors that caused the most dominant Sirit is a lack of awareness of self or less of its sturdywalls of faith to comply with religious law and customary law, economic factors, and self-controlfactor (liver). Sirit is done by means of deceit, coercion and even violence and some aresexually abused. Sirit can not be justified because Islam does not teachsuch things, as explained in Firman of Allah and the Hadis is the Hadis is more concerned with the right of a woman to decide a case which is about the marriage of their own. If viewed from the eyes of urf the tradition Sirit is customary imperfect, that is not in accordance with the texts of Personality 'so that this tradition must be rejected or abandoned.
\end{abstract}

Keywords: Sirit, Lampung tribe, Islamic Family Law.

\begin{abstract}
Abstrak
Perkawinan merupakan salah satu sunnatullah yang berlaku untuk semua makhluk Allah SWT yang bernyawa. Sirit adalah membawa lari perempuan dengan cara paksa, akal tipu daya, bahkan kekerasan untuk dinikahi. Problematika nya, bahwa sirit tidak sesuai dengan konsep perkawinan dalam Islam menyebutkan sahnya pernikahan jika memenuhi syarat-syarat perkawinan yaitu adanya kerelaan antara dua calon pasangan. Permasalahan yang dibahas yaitu tradisi sirit masyarakat suku Lampung Perspektif Hukum Keluarga Islam. Tujuan (1) Mengetahui faktor-faktor yang menyebabkan terjadinya sirit masyarakat suku Lampung, (2) Menjelaskan operasional/pelaksanaan sirit dan dampak sirit, (3)Menganalisis sirit masyarakat
\end{abstract}


suku Lampung dalam perspektif Hukum Keluarga Islam. Metode pengumpulan data berupa wawancara dan dokumentasi. Metode analisis data menggunakan metode kualitatif. Berdasarkan hasil analisis disimpulkan Faktor-faktor yang menyebabkan terjadinya sirit yaitu kurangnya kesadaran diri atau kurang kokoh nya tembok keimanan untuk mentaati hukum agama dan hukum adat, faktor ekonomi, dan faktor pengendalian diri (hati). Sirit dilakukan dengan cara tipu daya, paksaan bahkan dengan kekerasan serta ada juga yang mengalami pelecehan seksual. Sirit tidak dibenarkan dalam Islam, sebagaimana diterangkan dalam Firman Allah SWT dan hadis yaitu dalam hadis lebih mementingkan hak seorang perempuan dalam memutuskan sesuatu yaitu mengenai pernikahan mereka sendiri. Jika dilihat dari urf', tradisi sirit merupakan adat yang fasid, tidak sesuai dengan nash-nash syara sehingga tradisi ini wajib ditolak atau ditinggalkan.

Kata Kunci: Sirit, Suku Lampung, Hukum Keluarga Islam.

\section{Pendahuluan}

Perkawinan merupakan salah satu sunnatullah yang berlaku untuk semua. Dengan tujuan untuk memperoleh kebahagiaan dan kesejahteraan lahir batin menuju kebahagiaan dan kesejahteraan dunia dan akhirat. Kompilasi Hukum Islam Bab II pasal 2, menyatakan bahwa perkawinan menurut hukum Islam adalah pernikahan yaitu akad yang sakral dan agung dalam sejarah perjalanan hidup manusia yang dalam Islam disebut sebagai miitsaaqan gholiidhan, yaitu akad yang sangat kuat untuk mentaati perintah Allah dan melaksanakannya merupakan ibadah. ${ }^{1}$

al-Qur`an juga menjelaskan bahwa manusia secara naluriah, sangat menyukai lawan jenisnya, untuk itu Islam menetapkan suatu ketentuan yang harus dilalui dengan memberikan jalan keluar yang terbaik mengenai hubungan manusia yang berlainan jenis tersebut, yaitu perkawinan, dan selanjutnya dari perkawinan tersebut akan melahirkan anak keturunan, memperoleh harta kekayaan, dan lainlain. Hal tersebut sesuai dengan firman Allah dalam surat Ar-Rum ayat 21 yang berbunyi :

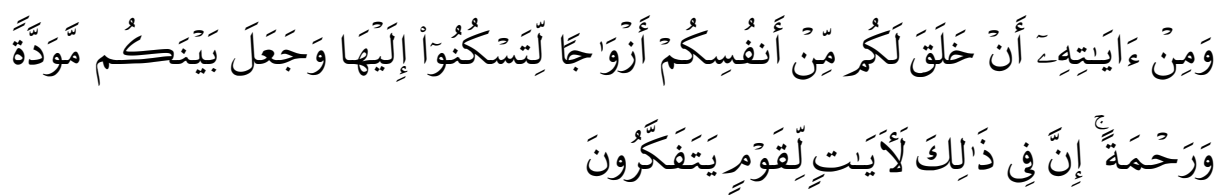

${ }^{1}$ Abdurrahman, Kompilasi Hukum Islam di Indonesia, (Jakarta: CV Akademika Pressindo, 2010), h. 114. 
Artinya:"Dan di antara tanda-tanda kekuasaan-Nya ialah Dia menciptakan untukmu isteri-isteri dari jenismu sendiri, supaya kamu cenderung dan merasa tenteram kepadanya, dan dijadikan-Nya diantaramu rasa kasih dan sayang. Sesungguhnya pada yang demikian itu benar-benar terdapat tanda-tanda bagi kaum yang berfikir". ${ }^{2}$

Berdasarkan ayat di atas dapat dipahami bahwa Islam tidak menyetujui seorang Muslim memilih hidup membujang. Namun sebaliknya, Islam justru memerintahkan umat Islam untuk menikah. Tujuan perkawinan dalam Islam, pada hakikatnya bukan semata-mata untuk kesenangan lahiriah melainkan juga membentuk suatu ikatan kekeluargaan, pria dan wanita dapat memelihara diri dari kesesatan dan perbuatan tidak senonoh. Tujuan perkawinan yang lainnya adalah memenuhi kebutuhan persuami istrian yang wajar dan melahirkan keturunan serta memeliharanya untuk menciptakan kenyamanan dan kebahagiaan.

Sabda Rasulullah SAW sebagai berikut:

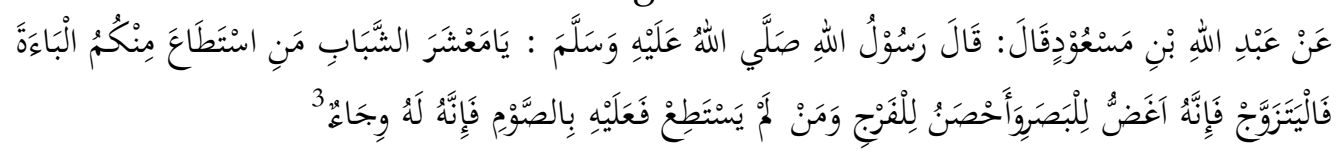

Artinya: "Dari Abdullah bin Mas'ud ra, dia berkata: 'Rasulullah SAW bersabda: 'Wahai sekalian pemuda! Barang siapa di antara kalian yang sudah mampu menyediakan sarana untuk menikah, maka hendaklah kalian menikah, karena sesungguhnya pernikahan itu lebih dapat menahan pandangan mata dan lebih dapat menjagakemaluan. Dan barang siapa yang tidak mampu, maka hendaklah ia shaum (berpuasa), karena shaum itu merupakan penawar syahwat baginya. ${ }^{4}$

Hadist di atas menjelaskan bahwa karena menjaga kehormatan dan menahan hawa nafsu itu merupakan kewajiban, sementara para pemuda memiliki dorongan hawa nafsu yang sangat kuat, maka Rasulullah SAW menyeru mereka untuk memelihara kehormataan mereka,dengan cara, bagi mereka yang mendapatkan sarana untuk menikah, berupa maskawin, nafkah dan tempat tinggal, maka hendaklah menikah, karena pernikahan itu dapat menahan pandangan

2Departemen Agama RI,Qur'an Tajwid dan Terjemah (Jakarta : Maghfirah Pustaka, 2006), h. 406.

${ }^{3}$ Abdullah bin Abdurrahman Ali Bassam, Taisir Al-'Alam Syarhu Umdathi AlAhkam, (Kairo: Dar Al-Azhar, 2009), h. 616.

${ }^{4}$ Abdullah bin Abdurrahman Ali Bassam, Terjemah Syarah Hadits Pilihan Bukhari-Muslim, ( Jakarta: Darul-Falah, 2004), h. 742. 
mata dari hal-hal yang diharamkan untuk dipandang dan memelihara farji' dari berbagai perbuatan keji. Adapun orang yang tidak sanggup menyediakan sarana pernikahan, beliau memerintahkannya untuk berpuasa, karena puasa itu mendatangkan pahala dan sekaligus mampu meredam hawa nafsu dan melemahkannya, karena orang yang berpuasa tidak makan dan minum, sehingga nafsunya melemah dan dapat menutup semua pembuluh darah yang menjadi tempat masuknya syetan, karena puasa dapat meredam hawa nafsu. ${ }^{5}$

Masalah-masalah yang berkaitan dengan hal perkawinan sangat diperhatikan demi menjaga sakralitas dari perkawinan itu sendiri. Realita kehidupan menunjukkan bahwa perkawinan berlaku di seluruh dunia termasuk Indonesia. Di Indonesia juga begitu banyak suku dan adat istiadat, yang setiap suku mempunyai aturan adat istiadat yang berbeda-beda termasuk dalam hal perkawinan dan peminangannya banyak aturan adat yang digunakan, contohnya masyarakat suku Lampung. Perkawinan masyarakat suku lampung berbentuk perkawinan jujur di mana telah dikatakan bahwa perkawinan jujur tersebut pelamaran dilakukan oleh pihak pria.

Masyarakat penduduk asli Lampung bersifat genealogis patrilineal. Di mana kepengurusan pemerintahan adat kekerabatannya dipegang oleh keluarga kebuwaian (keturunan) menurut garis laki-laki. Di daerah Lampung dalam pengambilan sampai pelaksanaan pernikahan diatur dalam hukum adat yang dipimpin atau dibimbing oleh ketua adat.6Perkawinan menurut hukum adat pada umumnya di daerah Lampung dapat dilakukan dengan dua cara yaitu perkawinan dengan meminang dan perkawinan dengan tidak meminang/ kawin lari.

Kawin lari ini dapat dibedakan menjadi dua jenis yaitu kawin lari bersama dan kawin bawa lari. ${ }^{7 K a w i n ~ l a r i ~ b e r s a m a ~(k a w i n ~ s e b a m b a n g a n ~}$ yaitutindakan kawin lari untuk melaksanakan perkawinan yang disetujui si gadis dengan "tanda kepergiannya" berupa surat atau sejumlah uang) dan kawin bawa lari (kawin lari yang terdapat unsur pemaksaan atau dapat diartikan sebagai semacam penculikan (kawin bawa lari $)^{8}$, meskipun merupakan salah satu cara perkawinan dalam

${ }^{5}$ Abdullah bin Abdurrahman Ali Bassam, Terjemah Syarah Hadits Pilihan Bukhari-Muslim, h. 742-743.

6 Hilman Hadikusuma, Pengantar Hukum Adat Indonesia, (Bandung: Mandar Maju, 2003), h. 125.

7Djamanat Samosir, Hukum Adat Indonesia, h. 289.

8Surojo Wignjodipuro, Pengantar dan Asas-Asas Hukum Adat, ( Jakarta: PT Gunung Agung, 1982), h. 127. 
adat Lampung, namun cara perkawinan tersebut sebenarnya menyalahi aturan hukum adat atau pelanggaran terhadap hukum adat itu sendiri, akan tetapi karena hal itu sering terjadi, sehingga dianggap oleh masyarakat Lampung itu sendiri sebagai hal yang biasa, dan pada akhirnya perbuatan kawin lari tersebut menjadi sebuah tradisi yang membudaya.

Kecamatan Sukadana Kabupaten Lampung Timur adalah salah satu contoh kecamatan yang masyarakatnya masih ada yang melakukan kawin bawa lari atau kawin paksa (sirit). Sirit adalah bahasa sehari-hari yang dipakai masyarakat khususnya masyarakat adat Lampung Pepadun yaitu Lampung Sai Putih Abung Siwo Mego, dengan kata lain sebagai sebutan saja, tetapi aslinya diartikan sebagai perempuan atau gadis yang diambil secara paksa, akal tipu, tidak atas persetujuan si gadis dan tidak menurut tata tertib adat berlarian, bahkan dengan kekerasan untuk dinikahi. ${ }^{9}$ Atau Perkawinan lari paksaan (Belanda:schaak-huwelijk, Lampung: dibembangkan, ditekep, ditunggang, Bali:melegandong).$^{10}$

Sirit atau Kawin paksa ini bukanlah jenis perkawinan yang didasari cinta kedua belah pihak, bahkan ketika hal ini terjadi maka kasusnya akan menjadi rumit. Kerabat gadis akan menuntut dan akan terjadi baku hantam, sekalipun bukan didasari rasa cinta, perkawinan seringkali pula tetap berlangsung karena si gadis yang telah dibawa lari dianggap aib oleh masyarakat, karena secara hukum adat, perempuan yang telah dibawa lari oleh seorang laki-laki harus segera dinikahkan dengan laki-laki tersebut. Jika tidak dilakukan, maka kedudukan siperempuan yang telah dibawa lari akan menjadi tidak baik dimata adat. Bahkan, perempuan ini bisa dianggap tidak berharga lagi, sehinggauntuk memulihkan nama baik si perempuan, harus dilakukan semacam upacara adat yaitu perkawinan. Maka, daripada nama baiktercoreng lebih baik keluarga perempuan dan perempuan itu sendiri menyetujui perkawinan yang diminta oleh keluarga laki-laki.

Masyarakat yang melakukan sirit biasanya melakukan dengan cara diam-diam. Sirit tidak meninggalkan surat tengepik(surat pemberitahuan yang ditinggalkan di rumah si gadis pada saat sebambangan, biasanya surat ini diletakkan di bawah tempat tidurnya

\footnotetext{
9Wawancara, 10 September 2014, Adanan (Ketua Adat Penyimbang Kecamatan Sukadana).

${ }^{10}$ Djamanat Samosir, Hukum Adat Indonesia, h. 292.
} 
atau dilemari atau di tempat-tempat lainnya) ${ }^{11}$ dan tidak meninggalkan sejumlah uang adat seperti halnya adat larian yang berdasarkan tata cara adat larian atau sebambangan. Adat larian atau sebambangan yaitu tindakan kawin lari untuk melaksanakan perkawinan yang disetujui si gadis atau keinginan gadis yang disetujui bujang, terlepas dari ada atau tidak adanya persetujuan orang tua. ${ }^{12}$ Kasus sirit ini bahkan, perempuan diambil, mungkin tidak ada yang tahu, dan biasanya, si perempuan dibohongi dahulu, diajak nonton, ke pasar, atau main ke rumah teman.

Pada kasus sirit ini banyak korban yang mengalami tindak kekerasan dan pelecehan seksual. Tidak sedikit korban kemudian diculik dan dipaksa untuk melakukan hubungan intim dengan penculiknya,dalam proses penculikan inipun korban kerap mengalami intimidasi dan ancaman agar mau menikah dengan sipenculik yang notabenenya adalah seseorang yang ia kenal. ${ }^{13}$

\section{Pembahasan}

\section{Tradisi Sirit Masyarakat Lampung}

Sirit yang dilakukan masyarakat Kecamatan Sukadana Kabupaten Lampung Timur merupakan bentuk melarikan gadis dengan cara dipaksa, akal tipu, bahkan dengan kekerasan, sehingga telah dianggap keluar dari aturan hukum adat Lampung dan tidak dapat dibenarkan. Sirit ini merupakan suatu proses yang dilakukan sebelum perkawinan terjadi.

Laki-laki yang melakukan sirit akan dikenakan sanksi atau denda adat (uang adat) yang harus/wajib dibayarkan setiap pelanggar adat. Sirit yang dilakukan di Kecamatan Sukadana ini tidak dapat dibenarkan dan dapat dipidanakan di muka pengadilan, dengan pasal 332 KUHP, sebagai dasar pengaduan. Dan dalam Kompilasi Hukum Islam Pasal 71 huruf F berbunyi: "Perkawinan yang dilakukan dengan paksaan dapat dibatalkan". Berdasarkan penjelasan di atas maka sirit dalam perkawinan adat Lampung dapat dibatalkan karena mengandung unsur pemaksaan.

11Hilman Hadikusuma, Hukum Pidana Adat, ( Bandung: PT Alumni, 1989), h. 81.

12Djamanat Samosir,Hukum Adat Indonesia, h. 291-292.

13Wawancara, 10 September 2014, Adnan (Ketua Adat Penyimbang Kecamatam Sukadana). 
Menurut pandangan Islam perbuatan kawin sirit tersebut bertentangan dengan agama karena selain penyebabnya berupa status sosial, penindasan hak asasi manusia, dan pemaksaan kehendak tanpa adaanya musyawarah antara para pihak, serta akibat yang ditimbulkan akan dapat menimbulkan dosa seperti terbukanya aib keluarga maupun perbuatan-perbuatan maksiat lainnya.

Sirit ini dapat merupakan solusi peminangan jika pada akhirnya terjadi pernikahan, meskipun demikian secara hukum keluarga Islam hal ini tidak dibenarkan, yaitu karena dalam sirit ini terdapat unsur pemaksaan, tipu daya dan kekerasan, yang tentunya hal ini bertentangan dengan syarat-syarat perkawinan yang seharusnya perkawinan itu harus didasari atas suka sama suka. ${ }^{14}$

Bagi orang Islam di Indonesia, sahnya perkawinan adalah apabila dilaksanakan sejalan dengan prinsip-prinsip hukum dalam Islam yaitu diantaranya wajib memenuhi rukun dan syarat-syarat perkawinan. Perkawinan yang merupakan perjanjian suci antara seorang pria dengan seorang wanita, menurut Islam seharusnya didasarkan atas asas:

a. Kesuka-relaan

b. Persetujuan ke dua belah pihak

c. Kebebasan memilih

d. Kemitraan suami dan isteri

e. Untuk selamanya

Tujuan utama perkawinan adalah membentuk keluarga yang sakinah (ketenangan) cinta dan kasih sayang, jika tujuan ini dapat dicapai secara sempurna, maka tujuan-tujuan lain dari perkawinan itu dapat terpenuhi. Dengan ungkapan lain, tujuan lain adalah sebagai pelengkap untuk memenuhi tujuan utama ini. Sebagaimana Firman Allah SWT Q.S Ar-Rum ayat 21, yang dimaksud dengan rasa kasih dan sayang adalah rasa tenteram dan nyaman bagi jiwa raga dan kemantapan hati menjalani hidup serta rasa aman dan damai, cinta kasih bagi kedua pasangan, dan hal tersebut akan dapat dirasakan jika suatu perkawinan itu didasari atas suka sama suka. Suatu rasa aman dan cinta kasih yang terpendam jauh dalam lubuk hati manusia sebagai hikmah yang dalam dari hikmah Allah kepada makhluk-Nya yang saling membutuhkan, sehingga jika rasa itu telah ada diantara kedua pasangan maka keharmonisan rumah tangga pun akan tercapai. sukadana).

14 Wawancara, 3 April 2015, Ustad Syamsudin (Tokoh Agama di Kecamatan 
Keharmonisan keluarga adalah situasi dan kondisi dalam keluarga di mana di dalamnya tercipta kehidupan beragama yang kuat, suasana yang hangat, saling menghargai, saling pengertian, saling terbuka, saling menjaga, dan diwarnai kasih sayang dan saling percaya sehingga memungkinkan anak untuk tumbuh dan berkembang secara seimbang. Untuk itu dalam upaya membina keharmonisan rumah tangga perlu diperhatikan berbagai aspek secara menyeluruh. Diantaranya peranan masing-masing isteri dan suami baik yang individual maupun yang dimiliki bersama.

Perkawinan haruslah didasari atas suka sama suka atau persetujuan kedua belah pihak, karena jika tidak didasari hal tersebut tidak akan tercapai tujuan utama dari perkawinan tersebut yaitu mencapai keharmonisan keluarga yaitu sakinah, mawaddah dan rahmah. Keluarga harmonis akan terbentu berkat upaya semua anggota keluarga yang saling berinteraksi dan berkomunikasi dalam satu keluarga. Upaya untuk membangun keharmonisan dalam keluarga diperlukan tiga pilar sebagai dasar dan sendi keluarga harmonis, yaitu: kasih sayang, keharmonisan, dan ekonomi. Hal tersebut tidak akan tercapai jika bahtera keluarga yang dijalani diawali dengan perkawinan yang dipaksakan.

Salah satu faktor yang terjadi jika perkawinan yang tidak didasarkan atas suka sama suka yaitu pertengkaran antara suami dan isteri, tidak hormat dan santunnya isteri terhadap baik itu kepada suaminya maupun keluarga suaminya, dan bahkan akan tidak terlaksananya atau terpenuhinya hak-hak dan kewajiban masingmasing suami isteri tersebut, sehingga jika hal itu terjadi maka akan sangat mempengaruhi terwujudnya dan bahkan tidak adanya keharmonisan di dalam kehidupan rumah tangga, serta hal tersebut juga dapat memberikan efek negatif yang sangat besar di dalam rumah tangga.

Upaya untuk menjaga langgengnya sebuah bahtera rumah tangga, Al-Qur'an menegaskan agar kedua belah pihak (suami isteri) harus saling memperlakuakan pasangannya dengan tiga sikap, yang tercermin dalam Al-Qur'an. Al-Qur'an Surat An-Nisa ayat 19, Allah SWT berfirman: 


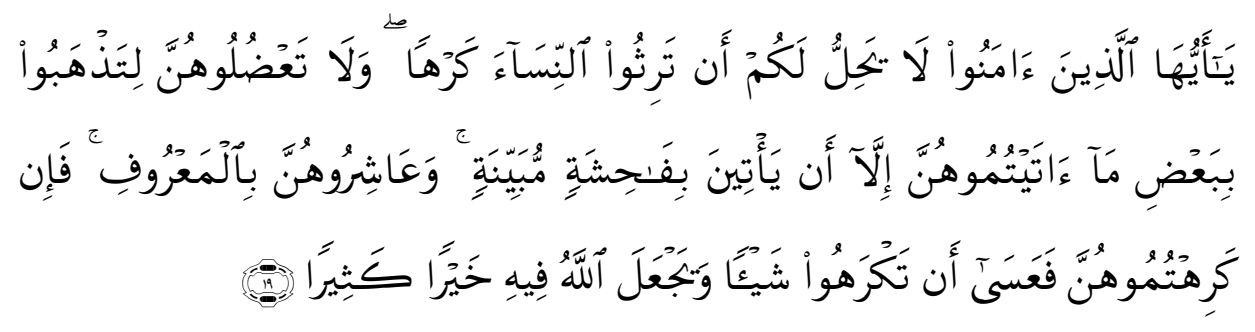

Artinya : "Hai orang-orang yang beriman, tidak halal bagi kamu mempusakai wanita dengan jalan paksa dan janganlah kamu menyusahkan mereka karena hendak mengambil kembali sebagian dari apa yang telah kamu berikan kepadanya, terkecuali bila mereka melakukan pekerjaan keji yang nyata. dan bergaullah dengan mereka secara patut. kemudian bila kamu tidak menyukai mereka, (maka bersabarlah) karena mungkin kamu tidak menyukai sesuatu, Padahal Allah menjadikan padanya kebaikan yang banyak". ${ }^{15}$

Ayat di atas secara tegas menunjukkan cara bergaul yang baik dalam keluarga. Pada intinya, baik suami maupun isteri harus saling menghormati dan berbuat baik, berarti secara tersirat dapat dikatakan bahwa ayat tersebut tidak membolehkan perkawinan yang dipaksakan, karena akan menimbulkan suatu sikap dimana suami isteri tidak dapat memenuhi tugas dan tanggung jawabnya sebagai suami isteri, yang pada akhirnya sikap saling menghormati, berbuat baik, saling pengertian, menyayangi, dan lain-lain tidak akan terwujud.

Terdapat banyak hadis yang mengemukakan bahwa tidak boleh memaksakan wanita untuk menikah tanpa persetujuan atau kerelaannya.

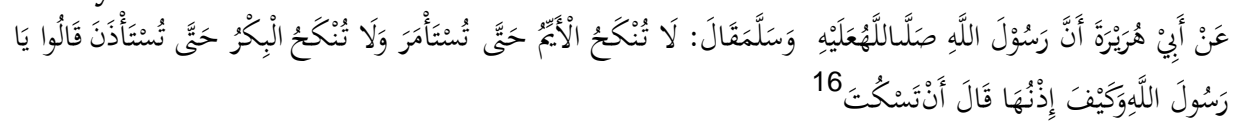

Dari Abu Hurairah RA, bahwa Rasulullah SAW bersabda, "Tidak boleh menikahkan seorang janda sebelum dimusyawarahkan dengannya dan tidak boleh menikahkan anak gadis (perawan) sebelum meminta izin darinya." Mereka bertanya, "Wahai

15 Departemen Agama RI, Qur'an Tajwid dan Terjemah, h. 80.

${ }^{16}$ Abu Abdillah, Muhammad bin Ismail al-Bukhari, Sahih al-Bukhari, (Kairo: Dar Ibn Hazm, 2010), h. 639. 
Rasulullah, bagaimana mengetahui izinnya?" Beliau menjawab, "Dengan ia diam (tidak berbicara)."17 (HR. Bukhari dan Muslim).

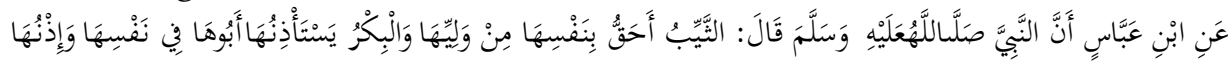
18 صُمَاتهُ 18

Dari Ibnu Abbas RA bahwasannya Nabi SAW bersabda, "Seorang janda lebih berhak atas dirinya daripada walinya, sedangkan perawan maka ayahnya harus meminta persetujuan dari dirinya. Dan persetujuannya adalah diamnya." (HR. Muslim)19

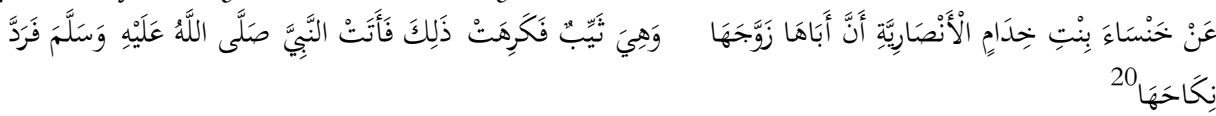

Dari Khansa' binti Khidzam al-Anshariyah RA: Bahwa ayahnya pernah menikahkan dia -ketika itu dia janda- dengan laki-laki yang tidak disukainya. Maka dia datang menemui Nabi SAW (untuk mengadu) maka Nabi SAW membatalkan pernikahannya."21 (HR. Bukhari)

Makna dari hadis-hadis di atas yaitu menjelaskan bahwa akad nikah merupakan akad yang teramat penting, karena seorang suami meminta pembolehan sesuatu yang amat dijaga wanita, yaitu hubungan persuami isterian. Melalui akad nikah ini dia menjadi tawanan di sisi suaminya, lalu suami dapat mengarahkannya menurut kehendaknya, Karena itulah pembuat syariat yang adil dan bijaksana menyerahkan keputusan kepada wanita, sehingga dia mempunyai kewenangan untuk memilih pasangan hidupnya, menjatuhkan pilihan menurut sisi pandangannya, karena dialah yang akan hidup bersama pilihannya dan dia sendiri yang tahu kecenderungan dan kesukaannya. ${ }^{22}$

Berdasarkan hadis-hadis di atas, Rasulullah SAW melarang wali menikahkan putrinya tanpa persetujuan atau kerelaannya. Ini jelas membuktikan bahwa hak anak (wanita) juga sangat mempengaruhi

17Zainuddin hamidy dan Fachruddin HS, Terjemah Shahih Bukhari, Jilid IV (Jakarta: Widjaya, 1992), h. 12.

18 Abu al-Husain, Muslim bin Hajjaj al-Naisaburi, Sahih Muslim, Kairo: alMaktabah al-Islamiyah, 2011, h. 305.

${ }^{19}$ Muhammad Fuad Abdul Baqi, Terjemah Shahih Muslim, Jilid 2 (Jakarta: Pustaka as-Sunnah, 2010), h. 729.

20 Abu Abdillah, Muhammad bin Ismail al-Bukhari, Sahih al-Bukhari, (Kairo: Dar Ibn Hazm, 2010), h. 639.

${ }^{21}$ Zainuddin hamidy dan Fachruddin HS, Terjemah Shahih Bukhari, Jilid IV (Jakarta: Widjaya, 1992), h. 12.

22 Abdullah bin Abdurrahman Ali Bassam, Terjemah Syarah Hadits Pilihan Bukhari-Muslim, h. 760-761. 
dalam perkawinan, sedangkan sirit dalam masyarakat adat Lampung sangat bertentangan dengan hadis tersebut, karena sirit mengandung unsur pemaksaan di dalamnya, yang dalam hal ini laki-laki memaksakan wanita untuk menikah dengannya bahkan prosesnya pun melalui tipu daya, ancaman, bahkan kekerasan.

Hadis-hadis tersebut tidak mengajarkan unsur pemaksaan karena di dalam hadis tersebut dijelaskan ada hak gadis atau wanita dalam memutuskan suatu hal yaitu pernikahan, jadi wali saja tidak boleh memaksa anak gadis atau wanita yang dibawah perwaliannya untuk menikah, apalagi dalam kasus sirit ini yang jelas-jelas yang memaksa menikah adalah notabenenya orang lain, hal demikian tentunya sangat dilarang dalam Islam.

Perkawinan di Indonesia tidak dilihat sekedar sebagai hubungan kontraktual antara laki-laki dan perempuan saja. Hukum Islam memandang perkawinan sebagai sebuah institusi yang terdiri dari tiga unsur yaitu : legal, sosial dan agama. ${ }^{23}$ Agama sesungguhnya dapat dipandang sebagai suatu bentuk hukum apabila dilihat dari definisi yang ditawarkan oleh masyarakat Indonesia secara umum.

Adat pada esensinya dipahami sebagai norma yang mengikat dan dipelihara dalam masyarakat dalam rangka kepentingan mereka mengatur kehidupan sehari-hari masyarakat. Adat kebiasaan yang sudah mengakar dalam kehidupan masyarakat selama kebiasaan tersebut tidak mendatangkan kerusakan atau menyalahi norma umum dan ajaran agama maka adat dapat diterima dan berjalan terus sebagai salah satu dasar dalam pengambilan keputusan hukum. Dalam adat tradisi sirit yang terjadi di Kecamatan Sukadana Kabupaten Lampung Timur, adat tersebut telah ada sejak dahulu dan masih terjadi hingga sekarang, bila fenomena tersebut dikaitkan dengan hukum Islam maka fenomena adat tersebut tidak lepas dari adanya 'urf.

Setiap masyarakat mempunyai sistem sosial yang berbeda antara satu dan yang lain, maka hukum Islam pun berkembang dengan bentuk-bentuk yang berbeda pula, perkembangan hukum Islam yang berbeda tersebut salah satunya ditandai dengan adanya Urf. 'Urf yaitu sumber hukum yang mendasarkan diri pada adat dan kebiasaan masyarakat setempat.

'Urf sendiri dibagi menjadi dua macam, yaitu:

1. 'Urf ditinjau dari kualitasnya (bisa diterima dan ditolaknya oleh syari'ah) 'urf ini dibagi menjadi dua macam, yaitu:

${ }^{23}$ Ratno Lukito, Trasidi Hukum Indonesia, (Yogyakarta: Teras, 2008), h. 107. 
a. 'Urfyang fasid atau 'urf yang batal, yaitu yang bertentangan dengan syariah, seperti kebiasaan minum-minuman keras saat merayakan pesta kelahiran.

b. 'Urf yang shahih atau Al-Âdah al-shahihah yaitu 'urf yang tidak bertentangan dengan syara', seperti memesan barang dagangan.

2. 'Urf ditinjau dari ruang lingkup berlakunya, yaitu mengenai adat dan kebiasaan kita, 'urf ini dibagi menjadi dua macam, yaitu:

a. Urf yang bersifat umum, yaitu adat kebiasaan yang berlaku untuk semua orang disemua negeri, Misalnya membayar bis kota dengan tidak menggunakan akad ijab qobul.

b. 'Urf yang khusus, yaitu hanya berlaku disuatu daerah tertentu saja, Misalnya adat gono-gini dalam adat jawa.

Syarat-Syarat Urf yang dapat dijadikan sumber penetapan hukum, yaitu:

1. Tidak bertentangan dengan nash yang qat'i.

2. Urf harus berlaku universal. Tidak dibenarkan urf yang menyamai Urf lainnya karena adanya pertentangan antara mereka yang mengamalkan dan yang meninggalkan.

3. Urf harus berlaku selamanya. Tidak dibenarkan Urf yang datang kemudian. ${ }^{24}$

Berkait dengan keterangan ' $u r f$ diatas, terdapat kaidah ushul fiqh yang berbunyi:

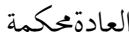

"Adat kebiasaan dapat ditetapkan sebagai hukum"

Dasar kaidah ini adalah

Q.S al-Baqarah ayat 236

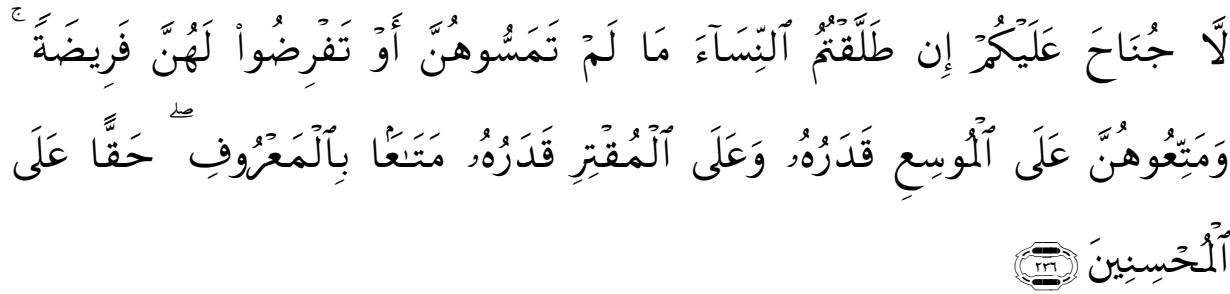

Artinya: "Tidak ada kewajiban membayar (mahar) atas kamu, jika kamu menceraikan isteri-isteri kamu sebelum kamu bercampur dengan mereka dan sebelum kamu menentukan maharnya. dan hendaklah kamu berikan suatu mut'ah (pemberian) kepada mereka. orang yang mampu menurut

${ }^{24}$ Rachmat Syafe'I, Ilmu Ushul Figh, h. 76. 
kemampuannya dan orang yang miskin menurut kemampuannya (pula), Yaitu pemberian menurut yang patut. yang demikian itu merupakan ketentuan bagi orang-orang yang berbuat kebajikan". 25

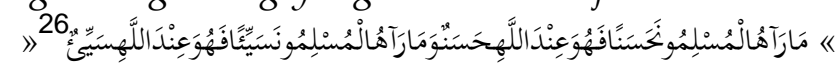
"Apa saja yang dipandang kaum muslimin merupakan kebaikan maka ia di sisi Allah juga merupakan kebaikan. Dan apa saja yang dipandang kaum muslimin merupakan keburukan maka ia di sisi Allah juga merupakan keburukan." (HR. Ahmad, no: 3600).

Al-'Urf dan Al-A'adalah searti, yang keduanya harus betul-betul telah berulang-ulang, sehingga melekat pada jiwa, diterima dan dibenarkan oleh akal dan pertimbangan yang sehat tabiat yang sejahtera. Hal yang demikian itu tentu merupakan hal yang bermanfaat dan tidak bertentangan dengan syaraa', sehingga merupakan apa yang dimaksud oleh hadis di atas yaitu apa yang dipandang baik oleh kaum muslimin, maka baik pula disisi Allah. ${ }^{27}$

Adapun syari'at Islam bukan untuk batas waktu tertentu, bukan untuk bangsa dan tempat tertentu tetapi bersifat universal, untuk seluruh alam. Alasan itulah kaidah-kaidah hukumnya bersifat umum, prinsip dan pokok-pokok saja yang disebutkan dan diberi kesempatan kepada ilmuan bidang hukum dan sosial ditempat masing-masing untuk menguraikannya lebih lanjut dalam mengatasi berbagai masalah yang timbul di daerahnya masing-masing. Hendaknya hukum mengakomodasi problematika masyarakat seiring dengan perkembangan zaman, dengan ini, akan tercermin fleksibilitas dan elastisitas proses pembentukan suatu hukum, Islam merupakan agama yang dinamis dan sesuai dengan perkembangan zaman termasuk dalam masalah hukum. Lebih lanjut lagi apabila hukum itu ditetapkan berdasarkan adat, maka dapat berubah sejalan dengan perubahan waktu dan tempat, karena perbedaan keinginan manusia.

Adat perkawinan yang ada pada masyarakat Kecamatan Sukadana Kabupaten Lampung Timur merupakan adat yang ada sejak zaman dahulu, dan masih terjadi hingga sekarang, namun,

${ }^{25}$ Departemen Agama RI, Qur'an Tajwid dan Terjemah, h. 38.

${ }^{26}$ Imam Ahmad bin Hanbal, al-Musnad, (Riyadh: Bait al-Afkar al-Dauliyah, 1998), h. 337.

27 Abdul Mudjib, Kaidah-Kaidah Ilmu Fiqh, (Jakarta: Kalam Mulia, 2001), h. 45. 
walaupun adat tersebut telah terjadi sejak lama dan masih terjadi hingga sekarang, tradisi sirit ini tidak dapat di masukkan ke dalam kaidah ini yaitu dikarenakan tradisi sirit ini walaupun perbuatan yang dilakukan berulang-ulang namun perbuatan atau tradisi tersebut bertentangan dengan nash-nash syara' dan hikmah-hikmahnya.

Pada pelaksanaan tradisi sirit tidak ada pelaksanaan pertunangan terlebih dahulu, sedangkan menurut Islam sebelum pernikahan dianjurkan mengunakan pertunangan terlebih dahulu, agar kedua calon mempelai dan kedua keluarga bisa saling menjalin silaturahmi dan mengenal lebih jauh dengan adanya $t a^{\prime} a r u f$. Mekanisme pelaksanaan sirit rentan terjadi hal-hal yang tidak sesuai dengan norma agama, norma hukum, dan norma sosial, seperti halnya adanya tipu daya, ancaman, bahkan kekerasan dari pihak bujang terhadap pihak gadis, pihak bujang melarikan gadis dngan pemaksaan, hal ini sangat jauh dengan kaidah hukum Islam. Hal ini terkait dengan kaidah ushūl al-fiqh yaitu:

"Kemadhlorotan itu harus dihilangkan"

الضريزال

Dasar dari kaidah ini ialah Firman Allah SWT dan Hadis Nabi SAW:

Q.S Al'A'raf ayat 56

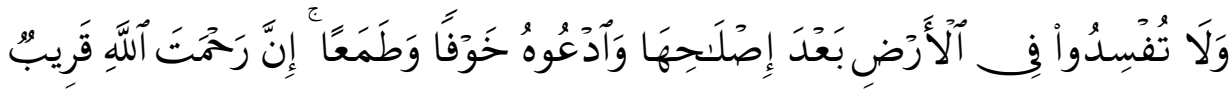

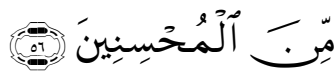

Artinya: "Dan janganlah kamu membuat kerusakan di muka bumi, sesudah (Allah) memperbaikinya dan Berdoalah kepada-Nya dengan rasa takut (tidak akan diterima) dan harapan (akan dikabulkan). Sesungguhnya rahmat Allah Amat dekat kepada orang-orang yang berbuat baik". 28

Q.S Al-Qasas ayat 77

${ }^{28}$ Dpartemen Agama RI, Qur'an Tajwid dan Terjemah, h. 157. 

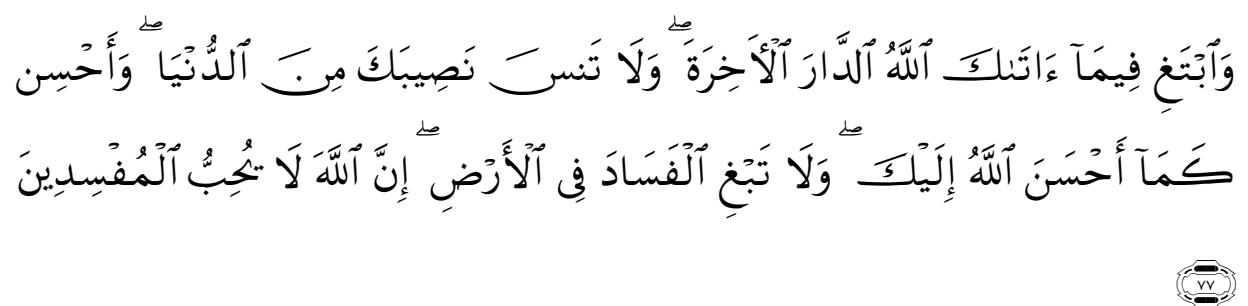

Artinya:"Dan carilah pada apa yang telah dianugerahkan Allah kepadamu (kebahagiaan) negeri akhirat, dan janganlah kamu melupakan bahagianmu dari (kenikmatan) duniawi dan berbuat baiklah (kepada orang lain) sebagaimana Allah telah berbuat baik, kepadamu, dan janganlah kamu berbuat kerusakan di (muka) bumi. Sesungguhnya Allah tidak menyukai orang-orang yang berbuat kerusakan". ${ }^{29}$

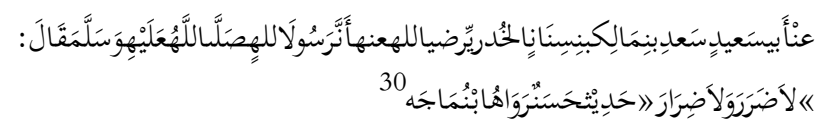

Dari Abu Sa'id, Sa'ad bin Malik bin Sinan al-Khudri RA, sesungguhnya Rasulullah SAW telah bersabda, "Janganlah engkau membahayakan diri sendiri dan orang lain." (HR. Ibnu Majah, no: 2341).

Makna yang terkandung dalam konsep kaidah ini, yang secara emplisit memotifasi kita untuk membuang jauh-jauh semua bahaya, baik bahaya bagi diri sendiri maupun bagi orang lain. Bahaya yang berwujud kesusahan, kesulitan atau kesempitan, baik didunia maupun di ahirat, sebisa mungkin harus disingkirkan, walaupun demikian bukan berarti segala kemudahan dan kenikmatan bisa direngkuh, sebab bisa jadi yang kita anggap baik atau maslahah ternyata berdampak negatif atau mafsadah bagi orang lain, bagi agama, bahkan bagi diri sendiri.

Penjelasan diatas menggambarkan bahwa tradisi sirit tersebut pelaksanaannya atau cara yang dilakukan tidak sesuai dengan ajaran hukum Islam dan hukum adat Lampung itu sendiri, dapat dikatakan bahwa tradisi sirit tidak diberlakukan pada semua wilayah, maka dapat dikatakan bahwa tradisi tersebut tidak berlaku universal dan tidak terdapat dalam nāsh atau syara', oleh karena itu tradisi sirit tidak memenuhi syarat 'urf yang dapat dijadikan sumber penetapan hukum, maka dapat

${ }^{29}$ Dpartemen Agama RI, Qur'an Tajwid dan Terjemah, h. 394.

${ }^{30}$ Abu Abdillah, Ibnu Majah, Sunan Ibnu Majah, (Kairo: Dar al-Fajr, 2010), h. 393. 
disimpulkan ketika dilihat dari segi kebiasaanyatradisi sirit dalam masyarakat Kecamatan Sukadana Kabupaten lampung Timur termasuk kategori al-'urf al-fäsid. Jadi, dengan demikian secara hukum Islam tradisi sirit ini sangat bertentangan, sehingga seharusnya tradisi ini ditolak.

Disisi lain, masyarakat Kecamatan Sukadana sebenarnya sangat mentaati hukum adat yang berlaku di daerah setempat termasuk dalam hal pelaksanaan perkawinan, seperti yang sudah dijelaskan bahwa tradisi sirit ini sebagian dilaksanakan karna faktor ekonomi, maka faktor biaya merupakan salah satu penghambat untuk mengadakan peminangan atau pelamaran. Dari penjelasan diatas, jika tinjauan dari segi ekonomi masyarakat maka tradisi sirit tersebut bisa juga membawa kepada kemaslahatan bagi masyarakat di Kecamatan Sukadana.

Upaya dalam mencetuskan hukum baru, fenomena budaya bukanlah sebuah dalil yang berdiri sendiri dan akan melahirkan produk hukum baru, melainkan "sekedar ornament" untuk meligitimasi hukum-hukum syariat, dan perlu dicatat pula, yang bisa dijadikan hukum hanyalah adat istiadat atau tradisi yang dinilai baik menurut perspektif syariah dan tentunya tidak bertentangan dengan nash-nash yang syar'i. Artinya, syariat hanya memberikan ketentuan secara umum, maka batasan pastinya diserahkan pada penilaian adat istiadat yang berlaku.

\section{Simpulan}

Sirit adalah perempuan atau gadis yang diambil secara paksa, akal tipu, tidak atas persetujuan si gadis dan tidak menurut tata tertib adat berlarian, bahkan dengan kekerasan untuk dinikahi. Sirit ini merupakan prosesi atau tata cara mengawali perkawinan atau tradisi sebelum perkawinan terjadi. Faktor-faktor yang menyebabkan terjadinya sirit yang paling dominan yaitu kurangnya kesadaran diri dalam mentaati perintah agama atau kurang kokoh nya tembok keimanan, faktor ekonomi, dan faktor hati yaitu rasa menyukai seseorang yang berlebihan dan tidak diikuti dengan fikiran atau hati nurani yang sehat, sehingga menimbulkan pemikiran bahwa seseorang yang kita sukai tersebut harus dapat dimiliki dengan cara apapun.

Operasional atau pelaksanaan sirit (tata cara sirit) yang dilakukan yaitu dengan akal tipu daya, magic, paksaan bahkan dengan 
kekerasan, dan lebih mengenaskan lagi ada yang tega menodai korban sirit terlebih dahulu dengan maksud agar korban sirit menyetujui perkawinan tersebut. Orang yang melakukan sirit akan dikenakan sanksi denda adat bagi yang menyetujui dan dapat pula diadukan kepada pihak kepolisian jika perempuan atau keluarga perempuan tidak menyetujui, serta sirit ini juga akan berdampak yang tidak baik, baik itu bagi diri pelaku dan korban maupun keluarga keduanya dan kehidupan rumah tangga mereka nantinya.

Menurut Hukum Keluarga Islam, sirit tidak dapat dibenarkan karena Islam tidak mengajarkan hal yang demikian, sebagaimana yang diterangkan dalam Firman Allah SWT dan hadis yang dipaparkan pada Bab sebelumnya, yaitu dalam hadis lebih mementingkan hak seorang perempuan dalam memutuskan suatu hal yaitu mengenai pernikahan mereka sendiri. Jika dilihat dari kacamata urf' maka tradisi sirit ini merupakan adat yang fasid, yaitu karena tidak sesuai dengan nash-nash syara' sehingga tradisi ini wajib ditolak atau ditinggalkan.[]

\section{DAFTAR PUSTAKA}

Abdullah bin Abdurrahman Ali Bassam, Taisir Al-'Alam Syarhu Umdathi al-Ahkam, Kairo: Dar Al-Azhar, 2009.

---_----, Terjemah Syarah Hadits Pilihan Bukhari-Muslim, Jakarta: Darul-Falah, 2004.

Abdul Mudjib, Kaidah-Kaidah Ilmu Figh, Jakarta: Kalam Mulia, 2001.

Abdurrahaman, Kompilasi Hukum Islam Di Indonesia, Jakarta: Akademika Pressindo, 2010.

Abu Abd Allah Muhammad Khathib al-Tibrizi, Misykat al-Mashabih, Beirut: Dar al-Kutub al-Ilmiyah, 2007, Jilid 1.

Abu Abdillah, Muhammad bin Ismail al-Bukhari, Shahih al-Bukhari, Kairo: Dar Ibnu Hazm, 2010.

Abu Abdillah, Ibnu Majah, Sunan Ibnu Majah, Kairo: Dar al-Fajr, 2010. Abu al-Husain, Muslim bin Hajjaj al-Naisaburi, Sahih Muslim, Kairo: al-Maktabah al-Islamiyah, 2011.

Abu Daud, Sulaiman bin al-Asy'as al-Sajistani al-Azdi, Sunan Abi Daud, Beirut: Dar Ibnu Hazm, 1998. 
Abu Malik Kamal bin as-Sayyid Salim, Shahih Fiqih Sunnah, Kairo: Maktabah at-Taufiqiyah, 1424 H/2003 M.

Ahmad Mudjab Mahalli, Wahai Pemuda Menikahlah, Yogyakarta: Menara Kudus, 2002.

Ahmad Rafiq, Hukum Islam Di Indonesia, Jakarta: PT. Raja Grafindo Persada, 2000.

Ali Yusuf As-Subki, Figh Keluarga, Jakarta: AMZAH, 2010.

Amir Syarifuddin, Hukum Perkawinan Islam di Indonesia, Jakarta: Kencana, 2011.

Amiur Nuruddin dan Azhari Akmal tarigan, Hukum Perdata Islam Di Indonesia, Prenada Media: Jakarta, 2004.

Burhan Ashshofa, metode penelitizan Hukum, Jakarta: Rineka Cipta, 2004.

Deddy Mulyana, Metodologi Penelitian Kualitatif, (Bandung: PT Remaja Rosdakarya, 2010

Dedi Junaiedi, Bimbingan Perkawinan Membina Keluarga Sakinah Menurut al-Qur'an dan As-Sunnah, Jakarta: Akademika Pressindo, 2000.

Departemen Agama RI, Qur'an Tajwid dan Terjemah, Jakarta: Maghfirah Pustaka, 2006.

Departemen Pendidikan Nasional, Kamus Besar Bahasa Indonesia, Jakarta: Balai Pustaka, 2002.

Didi Jubaidi Ismail, Membina Rumah Tangga Islami di bawah Ridha Allah, Bandung: Pustaka Setia, 2000.

Djamanat Samosir, Hukum Adat Indonesia, Bandung: CV. Nuansa Aulia, 2013.

Edi Kusnadi, Metodologi Penelitian: Aplikasi Praktis, (Jakarta dan Metro: Ramayana Pers dan STAIN Metro, 2008.

H. S. A. Al-Hamdani, Risalah Nikah (Hukum Perkawinan Islam), terj. Agus Salim, Jakarta: Pustaka Amani, 2002.

Hermawan warsito, Pengantar Metodologi Penelitian, Jakarta: Gramedia, 1976.

Hilman Hadikusuma dkk, Adat-Istiadat Lampung, Bandar Lampung: Dinas Pendidikan dan Kebudayaan Lampung, 1983.

Aditya Bakti, 1985. , Hukum Perkawinan Adat, Bandung:PT. Citra Hukum kekerabatan Adat, Jakarta : Fajar Agung, 1987. 
-, Hukum Pidana Adat, Bandung: PT Alumni,

1989.

, Hukum Perkawinan Adat dan Adat Istiadat dan Upacara Adatnya, Bandung: Citra Aditya Bakti, 2003.

Mandar Maju, 2003. , Pengantar Hukum Adat Indonesia, Bandung: Hukum Perkawinan Indonesia menurut :Perundangan, Hukum Adat, dan Hukum Agama, Bandung : Mandar Maju, 2007.

H.S.M. Nasaruddin Latif, Ilmu Perkawinan Problematika Seputar Keluarga dan RumahTangga, Bandung: Pustaka Hidayah, 2001.

Husain Mazhahiri, Membangun Surga dalam Rumah Tangga, Bogor: Cahaya, 2004.

Ibnu Rusyd, Bidayatul Mujtahid Wanihayatul Muqtashid, Terj. Mad'ali jilid II, Bandung: Triganda Karya, 1996.

Ibrahim Amini, Bimbingan Islam Untuk Kehidupan Suami-Istri, Bandung: Al- Bayan, 1998.

Imam Ahmad bin Hanbal, al-Musnad, Riyadh: Bait al-Afkar alDauliyah, 1998.

Jonathan Sarwono, Metode Penelitian Kuantitatif dan Kualitatif, (Yogyakarta: Penerbit Graha Ilmu, 2006

Kamal Muchtar, Azas-azas Hukum Islam tentang Perkawinan, Jakarta: Bulan Bintang, 1974.

Khoiruddin Nasution, Hukum Perkawinan 1, Yogyakarta: Tazzafa, 2005.

------, Pengantar Dan Pemikiran Hukum Keluarga Perdata Islam Indonesia, Yogyakarta: Academia+TAZZAFA, 2010.

Koentjaraningrat, Metode-Metode Penelitian Masyrakat, Jakarta: Gramedia Pustaka Umum, 1994.

Lexy J. Moleong, Metode Penelitian Kulalitatif Edisi Revisi, (Bandung: PT Remaja Rosdakarya, 2013.

L.M. Syarifie, Cinta dan Perkawinan, Jatim: CV. Bintang Pelajar, tth.

Moeljatno, Kitab Undang-Undang Hukum Pidana, Jakarta: Bumi Aksara, 2007.

Mohammad Nasir, Metode Penelitian, Jakarta: Ghelia Indonesia, 1999.

Mohd. Idris Ramulyo, Hukum Perkawinan Islam: Suatu Analisis dari Undang-undang No. 1 Tahun 1974 dan Kompilasi Hukum Islam, Jakarta : PT Bumi Aksara, 2002.

Mufidah, Psikologi Keluarga Islam, Malang: UIN Malang Pers, 2008. 
Muhammad Fuad Abdul Baqi, Terjemah Shahih Muslim, Jilid 2, Jakarta: Pustaka as-Sunnah, 2010.

M. Hariwijaya dan Bisri M. Djaelani, Tekhnik Penulisan Skripsi dan Thesis, $\quad$ Cetakan 1, Jogjakarta: Zenith Publisher, 2004.

Muhammad Nashiruddin Al-Albani, Terjemah Shahih Sunan Abu Daud, Jakarta: Pustaka Azzam, 2012.

Muhyidin Abu Zakaria bin Syarof an-Nawawi, Syarah Muslim, Jilid 9, Riyadh: Maktabah al-Ma'arif, 1998.

Musa Turoichan, Kado Perkawinan, Surabaya: Ampel Mulia, 2009.

Rachmat Syafe'I, Ilmu-Ilmu Ushul Figh, Bandung: Pustaka Setia, 2007.

Ratno Lukito, Trasidi Hukum Indonesia, Yogyakarta: Teras, 2008.

Shahih Muslim, Bi Syarh al-Nawawi, Jilid 16 Cet. Ke -5, Maktabah alMa'arif: 1419/1998.

Sayuti Thalib, Receptio A Contrario, Jakarta: Bina Aksara, 1985.

Sayyid Sabiq, Figh Sunnah, Terj. Moh. Tholib, "Fiqih Sunnah 6", Bandung: PT. al- Maarif, 1994.

Sudarmawan, "Pelaksanaan Kawin Lari untuk Menerobos Ketidaksetujuan

Orangtua setelah Berlakunya UU No.1Tahun 1974 tentang

Perkawinan", Tesis Magister Kenotariatan Universitas

Dipenegoro Semarang, 2009

Sugiyono, Metode Penelitian Pendidikan, Bandung: Alfabeta, 2012.

Suharsimi arikunto, Prosedur penelitian Suatu Pendekatan, Jakarta: PT Rineka Cipta, 1997.

---_-----, Prosedur Penelitian : Suatu Pendekatan Praktik, Cet. XII, Jakarta : PT. Rineka Cipta, 2006.

Surojo Wignjodipuro, Pengantar dan Asas-Asas Hukum Adat, Jakarta: PT Gunung Agung, 1982.

Sutrisno hadi, Metodelogi Research, Jilid 1, Yogyakarta: Fakultas Psikologi, UGM.

Tatang M. Amirin, Menyusun Rencana Penelitian, Jakarta: Rajawali Pers, 1990.

Titik Riyani, "Tinjauan Hukum Islam terhadap Adat Lahi Kawin (Studi Kasus di Rejosari, Pamenang, Merangin, Jambi)", Tesis Fakulstas Syari'ah dan Hukum UIN Sunan Kalijaga Yogyakarta, 2011.

Tormenset Parlindungan, "Budaya Kawin Lari dan Akibat Hukumya pada Masyarakat Lampung Pepadun di Kecamatan Negeri Sakti Kabupaten Tanggamus Provinsi Lampung", Tesis Magister Kenotariatan Universitas Dipenegoro Semarang, 2004. 
Zaini Ahmad Noeh dan Abdul Basit Adnan, Sejarah Singkat Peradilan Agama Islam di Indonesia, Bina Ilmu: Surabaya, 1983.

Zainuddin Ali, Metode Penelitian Hukum, Jakarta: Sinar Grafika, 2011. 